UDC 621.318

A. Borisova, A. Machulyansky, Ph.D., M.Rodionov, Ph.D., V. Smilyk, Y. Yakimenko, Dr.Sc.

National Technical University of Ukraine "Kyiv Polytechnic Institute", st. Polytechnique, 16, Kiev, 03056, Ukraine.

\title{
Aluminum oxynitride dielectric films prepared by reactive sputtering
}

Influence of technological modes of synthesis of aluminum oxynitride films by a method of magnetron reactive sputtering on their physical and chemical parameters is probed. Studied by IR spectroscopy and Auger electron microscopy and elemental, phase and structural composition of the synthesized films. Features of spectral and electrophysical parameters of films are discussed. Chemical stability of films is probed. Recommendations about modes of synthesis of films of electrophysical parameters of films providing optimization on the given their operational properties are received. References 13, figures 3 , table 1.

Keywords: aluminum oxynitride film; magnetron reactive sputtering; dielectric strength; chemical resistance; thermal stability.

\section{Introduction}

Wide use of thin-film coverings in optoelectronics, in processing systems and information storages, laser technology, and also as power effective coverings results in need of development of metaldielectric materials with the given characteristics. One of the perspective directions of creation of such materials is formation of composition nanostructural metal-dielectric systems in which nanosized metal switching on is distributed in a dielectric matrix [1,2].

However, support of operational stability of nano-sized metal particles is the actual task (problem) of development of nano-sized systems. In operations [1], it is shown that stability of such composite systems is defined by properties of a dielectric component (matrix). In this regard, films aluminum oxynitride, which is widely used in electronic technology thanks to its properties, are of special interest $[3,4]$.

Analysis of modern methods of synthesis of aluminum oxynitride films gives grounds to prefer reactive magnetron sputtering, as it allows deposition at low temperature and ensure good adhesion to the substrate condensate [5-8]. To date, known for his work on development of processing techniques produce aluminum nitride films with optimized electrical and frequency characteristics [6,7]. At the same time, the structure and chemical composition of these films is not known. There is no evidence of their thermal and chemical stability, no recommendations formulated to the selection process conditions directed synthesis of aluminum oxynitride films with desired physical and chemical properties.

Aim is to study the thermo-chemical resistance, dielectric strength, optical characteristics, composition and structure of films based on aluminum oxynitride depending on the parameters of technological modes of synthesis by magnetron reactive sputtering.

\section{Experimental technique and materials}

The films were deposited on glass substrates and single-crystal silicon (plane (100) plates SBD$7,5)$ by reactive magnetron sputtering at a constant current in the argon/nitrogen. Variable parameters were discharge power $(200-500 \mathrm{~W})$, the residual gas pressure $\left(2 \cdot 10^{-3}-7 \cdot 10^{-7} \mathrm{~Pa}\right)$, substrate temperature $\left(25-300{ }^{\circ} \mathrm{C}\right)$, while spraying (10-120 min) and bias potential on the substrate (ground substrate, a negative voltage $(-50 \mathrm{~V})$, high potential of $50 \mathrm{~V})$.

Chemical resistance was evaluated according to the etching rate of the films and the substrate for a standard microelectronic technology etchants: concentrated nitric acid and sulfuric acid, a mixture of concentrated sulfuric acid and hydrogen peroxide in a 3:1 ratio, a mixture of $70 \%$ beam nitric acid, acetic acid and phosphoric acid in a ratio of 1:3:25 mixture of $70 \%$ aqueous potassium hydroxide solution and $3 \%$ aqueous sodium orthophosphate $8: 1$; concentrated mixture of ammonium fluoride and $10 \%$ hydrofluoric acid in a ratio of $3: 1$ [9].

Measurement of resistivity and dielectric strength (breakdown voltage) was performed according to standard procedures on structures condenser type Si - AIN - Al. The thickness and refractive index of the obtained films was calculated using a standard computer software program data from the ellipsometric measurement at a wavelength of $632,8 \mathrm{~nm}$ [10].

Elemental analysis for nitrogen, oxygen, aluminum films were performed using Auger electron spectroscopy [11]. The nature of the material of the films was studied by IR spectroscopy according to their differential (relative to pure silicon substrate), the transmission spectra in the $1000-400 \mathrm{~cm}^{-1}$ vibrations of an $\mathrm{Al}-\mathrm{O}$ and $\mathrm{Al}-\mathrm{N}[8,11]$. 
The thermal stability of the films was studied by changing the spectra after the additional annealing at a temperature of about $1000^{\circ} \mathrm{C}$ for $30 \mathrm{~min}$.

Results of measurements and their discussion
The synthesis conditions of the films (thickness 0,5-1,5 mm) and their composition and physical characteristics measured are shown in Table 1.

Table 1. Electrophysical properties of Aluminum Oxynitride Films

\begin{tabular}{|c|c|c|c|c|c|c|c|c|c|c|c|}
\hline \multirow{2}{*}{\multicolumn{3}{|c|}{$\begin{array}{l}\text { Technological pa- } \\
\text { rameters of a mode } \\
\text { of evaporation of } \\
\text { films }\end{array}$}} & \multirow{2}{*}{\multicolumn{3}{|c|}{$\begin{array}{c}\text { Physical parameters } \\
\text { of a film }\end{array}$}} & \multicolumn{6}{|c|}{ Chemical parameters of a film } \\
\hline & & & & & & \multicolumn{3}{|c|}{$\begin{array}{l}\text { Maintenance of } \\
\text { elements, at. \% }\end{array}$} & \multicolumn{3}{|c|}{ Etching rate, $\mathrm{nm} / \mathrm{s}$} \\
\hline 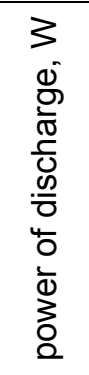 & 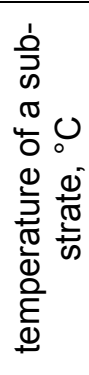 & 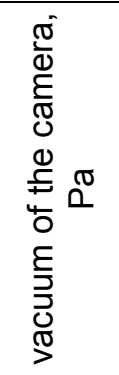 & 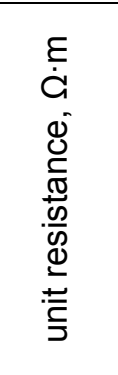 & 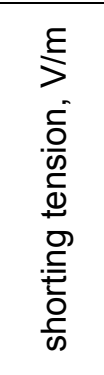 & 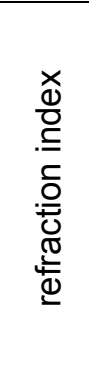 & $\mathrm{Al}$ & $\mathrm{N}$ & 0 & 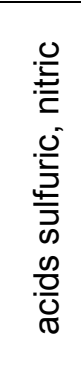 & 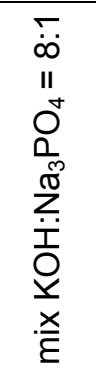 & 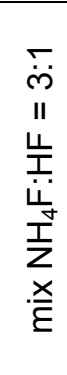 \\
\hline $\begin{array}{l}500 \\
300 \\
200 \\
200\end{array}$ & $\begin{array}{c}25 \\
100 \\
200 \\
200\end{array}$ & $\begin{array}{l}7 \cdot 10^{-5} \\
1 \cdot 10^{-4} \\
5 \cdot 10^{-4} \\
7 \cdot 10^{-4}\end{array}$ & $\begin{array}{l}1 \cdot 10^{9} \\
1 \cdot 10^{10} \\
5 \cdot 10^{8} \\
7 \cdot 10^{6}\end{array}$ & $\begin{array}{l}5 \cdot 10^{6} \\
2 \cdot 10^{7} \\
5 \cdot 10^{6} \\
8 \cdot 10^{5}\end{array}$ & $\begin{array}{l}1,92 \\
2,25 \\
1,60 \\
1,40\end{array}$ & $\begin{array}{l}55 \\
55 \\
50 \\
48\end{array}$ & $\begin{array}{c}23 \\
30 \\
8 \\
-\end{array}$ & $\begin{array}{c}1 \\
- \\
25 \\
44\end{array}$ & $\begin{array}{c}1,0 \\
1,0 \\
0 \\
0\end{array}$ & $\begin{array}{l}0,02 \\
0,01 \\
0,02 \\
0,05\end{array}$ & $\begin{array}{l}3,0 \\
3,0 \\
3,0 \\
3,0\end{array}$ \\
\hline
\end{tabular}

According to the detected content of aluminum, nitrogen and oxygen in the films synthesized by a formula of structure installed. At 55\% alumina content and $23-30 \%$ nitrogen, which corresponds to the ratio $\mathrm{Al}: \mathrm{N}=2: 1$, the film composition corresponding to the formula AIN, is confirmed that the obtained close to the atomic weight ratio of $\mathrm{Al}$ to the atomic weight of $N-27: 14=1,92: 1$. With a decrease in the nitrogen content up to $8 \%$ increase in the oxygen content and up to $25 \%$ with $50 \%$ aluminum ratio of these elements $(A 1: O: N=6: 3: 1)$ indicates the formation of aluminum oxynitride $\mathrm{Al}_{3} \mathrm{O}_{3} \mathrm{~N}_{4}$ composition, calculated as the ratio of the atomic weights of the elements this formula $(27 \times 3: 16 \times 3: 14=5.8: 3.4: 1)$ agrees well with the experimental data. Also synthesized by a film which consists predominantly of aluminum (48\%) and oxygen $(44 \%)$ of a $1: 1$ ratio with that composition can be represented by aluminum oxide $\mathrm{Al}_{2} \mathrm{O}_{3}$ ratio calculation of atomic weight $-27 \times 2: 16 \times 3=1,12: 1$. Besides the basic elements ( $\mathrm{Al}, \mathrm{O}$, and $\mathrm{N}$ ) according to the Auger spectra of the compositions in the films revealed 3-10 \% iron and 5-10 \% silicon, which can be associated with parts of the magnetron sputtering unit and the substrate. From the table it is also clear that as the oxygen enrichment of film materials refractive index decreases from 2,25 to 1,40 . Similar results were obtained for films of silicon nitride and silicon oxide [12].

Noteworthy is that the oxygen and $\mathrm{Al}_{2} \mathrm{O}_{3}$ film $\mathrm{Al}_{3} \mathrm{O}_{3} \mathrm{~N}$ formed at a discharge power of $200 \mathrm{~W}$ and pre-evacuation of the chamber to a pressure of residual gases $7 \cdot 10^{-4} \mathrm{~Pa}$, while the film of aluminum nitride AIN - at most 2 times the discharge power and 10 times fewer residual gas pressure. In this oxide film and aluminum oxynitride resistivity by 2-3 orders of aluminum nitride films are inferior. At the same time on chemical firmness, all three film materials differ among themselves a little.

From the data presented in Fig. 1 and 2 received a dependency of specific resistance and breakdown voltage of the temperature that the electrical characteristics are significantly improved when using RF bias on the wafers.

Thus, to obtain the $\mathrm{Al}_{2} \mathrm{O}_{3}$ film and $\mathrm{Al}_{3} \mathrm{O}_{3} \mathrm{~N}$ sufficient vacuum system to evacuate residual gas pressure of about $7 \cdot 10^{-4} \mathrm{~Pa}$, and sputtering to produce a discharge at a power of $200 \mathrm{~W}$ with the substrate heated to a temperature of $200^{\circ} \mathrm{C}$, and for the synthesis of AIN films need to preevacuation pressure of at least $7 \cdot 10^{-5} \mathrm{~Pa}$, using an RF bias potential on the substrate 50 and the dis-

(c) Borisova A., Machulyansky A., Rodionov M., Smilyk V., Yakimenko Y., 2015 
charge power of $300 \mathrm{~W}$ and $500 \mathrm{~W}$, respectively, to substrate 100 , and at a temperature of $25^{\circ} \mathrm{C}$.

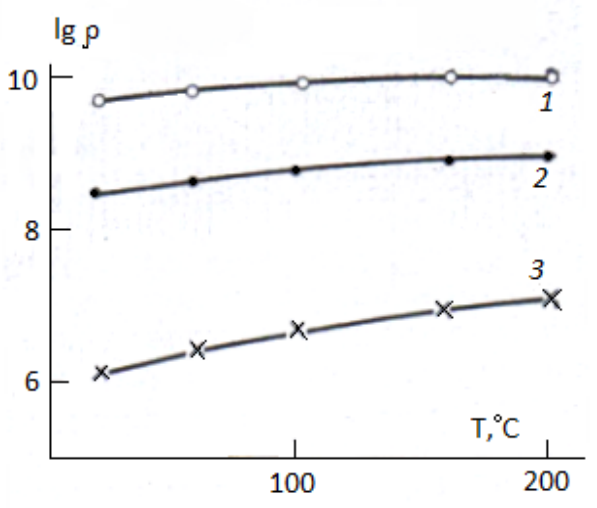

Fig. 1. Dependence of the resistivity aluminum oxynitride $\rho$-films on the substrate temperature: 1 - highbias potential $(50 \mathrm{~V}, 10 \mathrm{MHz})$ on the substrate 2 constant negative potential $(-50 \mathrm{~V})$ on the substrate, 3 - substrate grounded

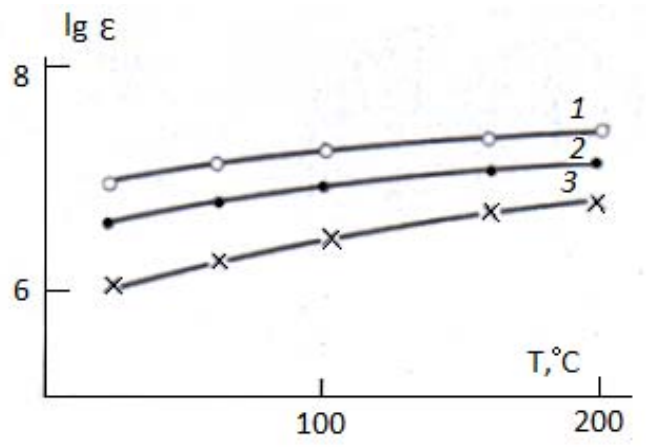

Fig. 2. Depending on the electric strength of $\varepsilon$ aluminum oxynitride films on the substrate temperature: 1 - high-bias potential $(50 \mathrm{~V}, 10 \mathrm{MHz})$ on the substrate 2 - constant negative potential $(-50 \mathrm{~V})$ on the substrate, 3 - substrate grounded

Fig. 3 shows the IR transmission spectra of the films studied in the spectral range $1000-400 \mathrm{~cm}^{-1}$, a typical manifestation of the oscillation frequencies of the tetrahedral $\left[\mathrm{AlO}_{4}\right]$ and octahedral $\left[\mathrm{AlO}_{6}\right]$ groups aluminosilicates, bauxite, spinel and single crystal, fine [1] and the film aluminum nitride [8, $11,12,13]$.

Very intense narrow band of $665 \mathrm{~cm}^{-1}$ range of aluminum nitride film (Fig. 1-3), according to the experimental [8] and calculated [12] data refers to fluctuations in $\mathrm{Al}-\mathrm{N}$ communication coordination tetrahedron $\left[\mathrm{AIN}_{4}\right]$ which is the main structural motif AIN wurtzite lattice. Discovered the identity of the position and shape of this band in the spectra of the film and crystalline aluminum nitride is the basis to assume that the synthesized AIN films are polycrystalline with a regular orientation of the structural elements. At the same time a very broad in- tense absorption around 760 and $700 \mathrm{~cm}^{-1}$ in the spectra of oxide films (Fig. 3, 2) and oxynitride (Fig. $3,3)$, respectively, aluminum may be indicative of the amorphous nature of these materials, since the presence of orientation and/or positional disorder molecular units of matter leads to a significant broadening of the spectral bands. Additional data on the nature of the synthesized film materials are received also in case of research of their thermal stability.

Thermal stability is estimated by comparing the IR spectra of the starting and annealed $\left(1000^{\circ} \mathrm{C}\right.$, $30 \mathrm{~min}$ ) film in a dry atmosphere and the water vapor. Identical spectra were obtained for all the annealed films ( $\mathrm{AIN}, \mathrm{Al}_{3} \mathrm{O}_{3} \mathrm{~N}, \mathrm{Al}_{2} \mathrm{O}_{3}$ ), so in Fig. 3, 4 shows a typical spectrum. New spectrum unlike raw spectra comprises two films intensive high relative to the spectra of the starting film 800 in doublets, 775 and $520,450 \mathrm{~cm}^{-1}$, which may be associated with a transition to a more ordered crystalline structure. Probably under the conditions of high temperature processing films passed their oxidation of modifications to the single-crystal aluminum oxide. This assumption is supported by the similarity of MK-detected spectra (Fig. 3, 4, 5) and annealed films corundum.

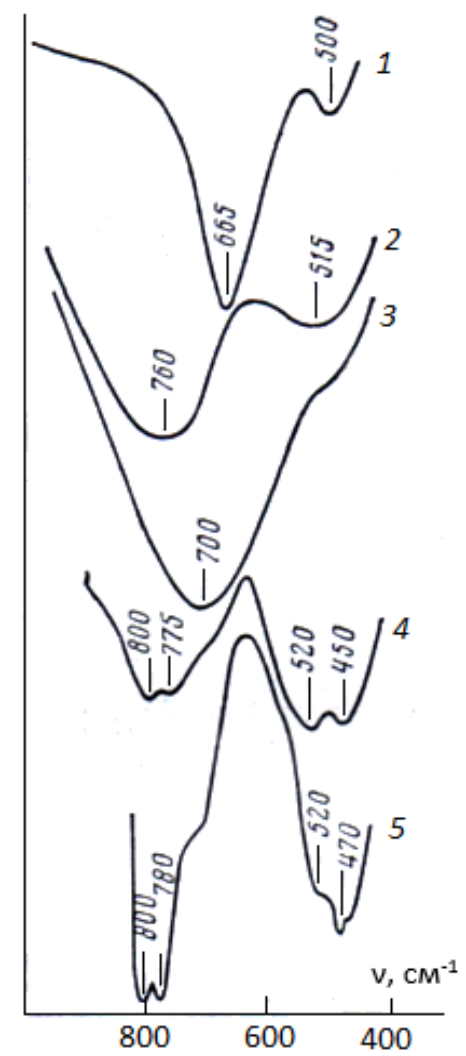

Fig. 3. Infrared transmission spectra of films: 1 AIN, $2-\mathrm{Al}_{2} \mathrm{O}_{3}, 3-\mathrm{Al}_{3} \mathrm{O}_{3} \mathrm{~N}, 4-\mathrm{AIN}$ after annealing at $1000^{\circ} \mathrm{C}, 5$ - potassium bromide tablet corundum ( $\alpha-$ $\mathrm{Al}_{2} \mathrm{O}_{3}$ ) 
Thus, with the help of IR spectra shows that the aluminum nitride AIN films are polycrystalline and are identified by a narrow intense band about 665 $\mathrm{cm}^{-1}$, and the oxide film $\mathrm{Al}_{2} \mathrm{O}_{3}$ and aluminum oxynitride $\mathrm{Al}_{3} \mathrm{O}_{3} \mathrm{~N}$ form a disordered structure and characterized by IR spectra in a broad intense band respectively at 760 and $700 \mathrm{~cm}^{-1}$.

\section{Conclusions}

The method of magnetron reactive direct current sputtering by a variation of technological modes of synthesis created films of different composition: AIN aluminum nitride, $\mathrm{Al}_{3} \mathrm{O}_{3} \mathrm{~N}$ aluminum oxynitride and $\mathrm{Al}_{2} \mathrm{O}_{3}$ aluminum oxide.

The assessment of the received films on unit resistance, breakdown strength, and coefficient of refraction, chemical stability and thermal stability is carried out.

It is shown (TABLE I) that the maintenance of the phase AIN in films can be raised in a directional way by change of technological parameters a ratio of reactive gases, capacities of discharge, temperature of a substrate and bias voltage given on it.

Synthetizing of a film can beat are recommended for use in electronics as browning and insulation layers and to formation on their basis of composition coverings with the given optical characteristics.

\section{References}

1. Zolotuhin, I. V., Kalinin, Ju. V., Sitnikov, A. V. (2006). Nanokompozitnye struktury na puti v nanojelektroniku [Nanocomposite structure on the way to nanoelectronics]. Priroda, No. 1, Pp.11-19. (Rus)

2. Machulyanskiy, A. V. (2007). High-frequency conductivity of nano-sized metal particles. Electronics \& Telecommunication. Part.1, Pp.41-45.

3. Beresnev, O. V., Sobol', D. A. (2012). Kolesnikov i dr. Fiziko-himicheskie i mehanicheskie svojstva nanostrukturnyh nitridnyh pokrytij N.M. [Physico-chemical and mechanical properties of nanostructured nitride coatings]. Metallofiz. novejshie tehnol, Vol.34, No. 2, Pp.139-160. (Rus)
4. Pogrebnjak, A. D., Muhammed, A. K. M. (2012). Properties of AIN films deposited to silicon substrates. International Journal of Structronics \& Mechatronics. Vol. 1, No. 2, Pp. 1-3.

5. Stafiniak, A., Muszynska, D., Szyszka, A., et al. (2009). Properties of AINx thin films prepared by $D C$ reactive magnetron sputtering. Optica Applicata. Vol.39, No. 4, Pp. 717-722.

6. Garcia-Mendez, M., Morales-Rodriquez, S., Machorro, R., et al. (2008). Characterixation of AIN thin films deposited by DC reactive magnetron sputtering. Revista mexicana de fisica. Vol. 54,No. 4, Pp.271-278.

7. Pogrebnjak, A. D., Muhammed, A. K. M., Ivashhenko, M. N., i dr. (2012). Strukturnye issledovanija plenok oksida cinka i nitrida aljuminija, roluchennyh metodami CVD i magnetronnogo raspylenija [Structural studies of zinc oxide films and aluminum nitride roluchennyh methods CVD and magnetron sputtering]. FIP, Vol. 10, No. 2, Pp. 177-182. (Rus)

8. Gerova, E. V., Ivanov, N. A., Kirov, K. J. (1981). Deposition of AIN thin films by magnetron reactive sputtering. Thin Solid Films, Vol. 86, No. 2, Pp. 201-206.

9. Rzhanova, A. V. (1982). Nitrid kremnija v elektronike. [Silicon nitride in electronics]. Novosibirsk, Nauka, P. 200. (Rus)

10. Rzhanova, A. V. (1983). Ellipsometrija - metod issledovanija poverhnosti [Ellipsometry - research method surface]. Novosibirsk, Nauka, P. 422. (Rus)

11. Jones, D. J., French, R. H., Mullejans, H., et al. (1999). Optical properties of AIN determined by vacuum ultraviolet spectroscopy and spectroscopic ellipsometry data. J. Mater. Res, Vol.14, No. 11, Pp. 4337-4344.

12. Anderson, A. M. (1977). Primenenie spektrov kombinacionnogo rassejanija. [Application of Raman spectra]. Moskva, Mir, P. 586.

13. Li, J., Nam, K. B., Nakarmi, M. L., et al. (2003). Band structure and fundamental optical transitions in wurtzite AIN. Appl. Phys. Lett, Vol.83, No. 25, Pp. 515-519. (Rus)

Поступила в редакцию 21 мая 2015 2. 
УДК 621.318

О.В. Борисова, О.В. Мачулянський, канд. техн. наук, М.К. Родіонов, канд. фріз.-мат. наук,

В. Смілик, Ю.І. Якименко, д.-р. техн. наук

Національний технічний університет України "Київський політехнічний інститут", вул. Політехнічна, 16, корпус 12, Київ, 03056, Україна.

\section{Діелектричні плівки оксинітриду алюмінію отримані реактивним розпиленням}

Вивчено вплив на електрофрізичні та хімічні властивочті діелектричних плівок оксинітриду алюмінію технологічних режимів їхнього формування методом реактивного магнетронного напилення. Досліджено методом ІЧ-спектроскопії, ОЖЕ-спектроскопії та електронної мікроскопії електронний та структурний склад синтезованих плівок. Обговорено властивості спектральних та електрофрізичних параметрів (питомого опору, електричної міцності, термічної стабільності та хімічної стійкості) плівок. Надано рекомендації щодо режимів синтезу плівок 3 метою забезпечення оптимізації електрофізичних параметрів на задані експлуатаційні властивості. Бібл. 13, рис. 3, табл. 1.

Ключові слова: плівки оксинітриду алюмінію; магнетроне реактивне розпилення; електрична міцність; хімічна стійкість; термічна стабільність.

\section{УДК 621.318}

А.В. Борисова, А.В. Мачулянский, канд. техн. наук, М.к. Родионов, канд. физ.-мат. наук,

В. Смилык, Ю.И. Якименко, д-р. техн. наук

Национальный технический университет Украины «Киевский политехнический институт», ул. Политехническая, 16, корпус 12, г. Киев, 03056, Украина.

\section{Диэлектрические пленки оксинитрида алюминия полученные ре- активным распылением}

Изучено влияние на электрофизические и химические свойства диэлектрических пленок оксинитрида алюминия технологических режимов их формирования методом реактивного магнетронного распыления. Исследован методом ИК - спектроскопии, ОЖЕ - спектроскопии и электронной микроскопии элементный и структурный состав синтезированных пленок. Обсуждены особенности спектральных и электрофизических параметров (удельного сопротивления, электрической прочности, термической стабильности и химической устойчивости) пленок. Даны рекомендации режимов синтеза пленок, обеспечивающих оптимизацию электрофизических параметров пленок на заданные эксплуатационные свойства. Библ. 13, рис. 3, табл. 1.

Ключевые слова: пленки оксинитрида алюминия; магнетронное реактивное распыление; электрическая прочность; химическая устойчивость; термическая стабильность.

\section{Список использованных источников}

1. Золотухин И.В., Калинин Ю.В., Ситников А.В. Нанокомпозитные структуры на пути в наноэлектронику. Природа.- 2006.- №1- С.11-19.

2. Machulyanskiy A.V. High-frequency conductivity of nano-sized metal particles. Electronics \& Telecommunication, 2007, Part.1, pp.41-45.

3. Береснев, О.В.Соболь, Д.А.Колесников и др. Физико-химические и механические свойства наноструктурных нитридных покрытий. Металлофизические новейшие технологии.-2012.T.34.-№2-C.139-160.

4. A.D. Pogrebnjak, A.K.M. Muhammed. Properties of AIN films deposited to silicon substrates. International Journal of Structronics \& Mechatronics., 2012, V1, №2, pp. 1-3.

5. A. Stafiniak, D. Muszynska, A. Szyszka et al. Properties of AlNx thin films prepared by DC reactive magnetron sputtering. Optica Applicata, 2009, V.39, № 4, pp. 717-722. 
6. M. Garcia-Mendez, S. Morales-Rodriquez, R. Machorro et al. Characterixation of AIN thin films deposited by DC reactive magnetron sputtering. Revista mexicana de fisica, 2008, V.54, № 4, P.271 278.

7. А.Д. Погребняк, А.К.М. Мухаммед, М.Н.Иващенко и др. Структурные исследования пленок оксида цинка и нитрида алюминия, полученных методами CVD и магнетронного распыления. ФИП.-2012.-Т.10.-№2-С.177-182.

8. Gerova E. V., Ivanov N. A., Kirov K. J. Deposition of AIN thin films by magnetron reactive sputtering. Thin Solid Films, 1981, V. 86, № 2, pp. 201-206.

9. Ржанова А.В. Нитирид кремния в электронике.-Новосибирск: Наука, 1982, 200с.

10. Ржанова А.В. Эллипсометрия - метод исследования поверхности.-Новосибирск: Наука, 1983, 422c.

11. D.J. Jones, R.H. French, H. Mullejans et al. Optical properties of AIN determined by vacuum ultraviolet spectroscopy and spectroscopic ellipsometry data. J. Mater. Res, 1999, V.14, № 11, pp. 4337-4344.

12. Андерсон А. М. Применение спектров комбинационного рассеяния- М.: Мир, 1977. - 586 с.

13. J. Li, K.B. Nam, M.L. Nakarmi et al. Band structure and fundamental optical transitions in wurtzite AIN. Appl. Phys. Lett, 2003, V.83, № 25, pp. 515-519.

(C) Borisova A., Machulyansky A., Rodionov M., Smilyk V., Yakimenko Y., 2015 